PR

46,7

1280

Received 20 September 2016 Revised 24 May 2017 Accepted 25 May 2017

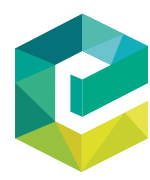

Personnel Review Vol. 46 No. 7, 2017 pp. $1280-1296$ Emerald Publishing Limited 0048-3486 DOI 10.1108/PR-09-2016-0243

\section{Employee share ownership and organisational performance: a tentative opening of the black box}

\author{
Keith Whitfield \\ Cardiff Business School, Cardiff University, Cardiff, UK \\ Andrew Pendleton \\ Durham University Business School, University of Durham, Durham, UK \\ Sukanya Sengupta \\ Department of Management, Royal Holloway College, \\ University of London, London, UK, and \\ Katy Huxley \\ Wales Institute of Social and Economic Research, Data and Methods, \\ Cardiff University, Cardiff, UK
}

\begin{abstract}
Purpose - A range of studies have shown that performance is typically higher in organisations with employee share ownership (ESO) schemes in place. Many possible causal mechanisms explaining this relationship have been suggested. These include a reduction in labour turnover, synergies with other forms of productivity-enhancing communication and participation schemes, and synergies with employer-provided training. The paper aims to discuss these issues.

Design/methodology/approach - This paper empirically assesses these potential linkages using data from the 2004 and 2011 British Workplace Employment Relations Surveys, and provides comparisons with earlier analyses conducted on the 1990 and 1998 versions of the survey.

Findings - Substantial differences are found between the 2004 and 2011 results: a positive relationship between ESO and workplace productivity and financial performance, observed in 2004, is no longer present in 2011. In both years, ESO is found to have no clear relationship with labour turnover, and there is no significant association between turnover and performance. There is, however, a positive moderating relationship with downward communication schemes in 2004 and in 2011 in the case of labour productivity. There is no corresponding relationship for upward involvement schemes.

Research limitations/implications - The results are only partially supportive of extant theory and its various predictions, and the relationship between ESO and performance seems to have weakened over time. Originality/value - The study further questions the rhetoric offered in support of wider ESO.
\end{abstract}

Keywords Quantitative, Organisational performance, Strategic HRM

Paper type Research paper

\section{Introduction}

Tom Redman was very sceptical about the power of financial participation schemes, and employee share ownership (ESO) in particular, to leverage higher organisational performance. His view was that, at the very least, such schemes needed to be part of a

(C) Keith Whitfield, Andrew Pendleton, Sukanya Sengupta and Katy Huxley. Published by Emerald Publishing Limited. This article is published under the Creative Commons Attribution (CC BY 4.0) licence. Anyone may reproduce, distribute, translate and create derivative works of this article (for both commercial and non-commercial purposes), subject to full attribution to the original publication and authors. The full terms of this licence may be seen at $\mathrm{http} / /$ creativecommons.org/licences/by/4.0/legalcode

Thanks are due to the sponsors of WERS2004 and 2011 - the Economic and Social Research Council, the Department of Trade and Industry (now the Department of Business, Innovation and Skills), the Advisory, Conciliation and Arbitration Service, the UK Commission for Employment and Skills, the National Institute of Economic and Social Research, and the Policy Studies Institute for their support of the 2004 and 2011 Workplace Employment Relations Surveys. 
coherent HRM package to have any chance of improving the organisational bottom line. Our attempts at trying to convince him that he was, perhaps, a little overly sceptical were typically met with a request to show him the evidence, much of which he found less than compelling. Unearthing new material on this relationship has therefore motivated much of our work. Every nugget of information that suggested that maybe financial participation mattered was seized on to present to Tom on the next occasion we had the pleasure of spending time in his company. Our discussions with him undoubtedly made us more circumspect in our support for a set of practices that we felt, in principle, should help organisations achieve their goals, and more discriminating in our approach to their analysis. This paper is the result of our latest work at this coal face.

Recent years have seen the advent of a wide range of worker-focussed, holistic approaches by firms in search of improved competitive performance in their product markets (Appelbaum and Batt, 1994; Paauwe, 2004; Whitfield and Poole, 1997). Amongst these practices, ESO has been accorded a key role in the process of leveraging improved performance via human resource management. It is seen as encouraging employees to identify more closely with their employing organisations, taking on board their values more fully, and thereby making a stronger contribution to their continued development (Blasi et al., 2016; Kurtulus and Kruse, 2017; Blasi et al., 2003; Gamble et al., 2002; Pendleton, 2006; Kaarsemaker et al., 2009; Robinson and Wilson, 2006; Kruse, 2016). It is believed that these processes will lead to enhanced organisational performance (Bryson and Freeman, 2010; Kruse et al., 2012; Poutsma and Braam, 2012; Robinson and Wilson, 2006; Sesil and Kroumova, 2007). As a result, ESO schemes have been promoted by policy makers and consultants in many countries.

Whilst there is widespread evidence that organisations with ESO schemes in place do indeed have higher performance (Fernie and Metcalf, 1995; McNabb and Whitfield, 1998; Pendleton and Robinson, 2010; Sengupta, 2008; Kurtulus and Kruse, 2017), there is considerable debate as to how share ownership plans promote these favourable effects. Several explanations can be found in the literature. Possibly the most common explanation is what has been a "golden path" approach. This suggests that ESO schemes have their main impact upon performance through improving affective commitment (employees' emotional attachment to, identification with and involvement in the organisation). An alternative view suggests that share ownership schemes are primarily an effective worker retention tool, and reduce labour turnover by making it financially lucrative for workers to remain in the firm and costly to exit (Marsden, 1999; Morris et al., 2006). Labour retention facilitates the development of human capital within the firm, leading to higher levels of employee and organisational performance. This has been called the "golden handcuffs" hypothesis.

The most common theoretical perspective in the ESO literature has drawn on principalagent theory, suggesting that employee share schemes align the interests of workers with those of their firms. However, a widely recognised limitation is the $1 / n$ or "free rider" problem that applies to all group incentives. To counter this, it has been argued that ESO needs to operate in conjunction with employee involvement and participation in decisions (Weitzman and Kruse, 1990). A synergistic relationship between ESO and these other forms of involvement have therefore been widely predicted, and there is evidence to support this. Finally, more recent contributions have highlighted the synergistic combination of ESO and training. Here it is argued that ESO can potentially signal mutual commitment and therefore encourage employers to offer training to employees (Pendleton and Robinson, 2011; Blasi et al., 2016).

The Workplace Employment Relations Surveys (WERS) of 2004 and 2011 provide good opportunities to examine these alternative processes through which ESO can influence performance. Furthermore, enhancements to the employee ownership questions in the 2004 
PR

46,7

and 2011 surveys enable a more precise evaluation of the role of share ownership than in preceding WERS surveys by listing specific share-ownership schemes, thereby allowing a more accurate representation of whether a workplace has such a scheme or not.

This paper evaluates the various ways that ESO is predicted to impact on workplace performance, and provides a comparative assessment of these routes. It provides indications of both contrasts and continuities with earlier results. In contrast to results from 1998, ESO is seen to have no significant relationship with labour turnover in either 2004 or 2011. Similar to studies using the 1998 data, however, there is evidence of synergy between ESO and downward communication, though this is stronger in 2004 than 2011. Upward participation is seen to have no independent or moderator effects on performance, echoing earlier studies. Finally, there is some modest evidence of synergies between levels of training and ESO in 2004, but this disappears by 2011. It is also clear that the effects of ESO are less potent in 2011. It seems that the recession of 2008-2009 may have been important here. It is noteworthy too that the coverage of ESO is considerably lower in 2011 than 2004: the proportion of private sector workplaces with ESO fell from 19 to 10 per cent. The paper makes a contribution by updating earlier analysis of ESO using WERS and also by systematically comparing the role of potential moderators which, hitherto, have been evaluated separately.

\section{Background}

ESO plans provide a means for employees to acquire equity in their employing firms. They can take several different forms, including share purchase schemes, free share awards, and stock options. Where shares are purchased, or options exercised by employees, it is common for discounts or matching shares to be offered by the employer as an incentive to join the plan and to mitigate risk. In many countries, employees participating in share ownership schemes also benefit from tax concessions, such as exemption from income tax on the benefit of acquiring shares at nil cost or a discount. The motives for promoting share ownership schemes vary between countries but a common objective is to provide employees with an incentive to work harder and smarter, by aligning their interests with those of their employer, thereby contributing to the improved performance of their company.

There has been extensive interest in the organisational impact of ESO plans in recent years, especially in the USA and UK (where these schemes are particularly widespread). Most of the empirical evidence has indicated that ESO plans have favourable effects on workplace and organisational performance (Kruse et al., 2012; Pendleton and Robinson, 2010; Pendleton, 2006; Blasi et al., 2016; Kurtulus and Kruse, 2017). The most common explanation for this finding has been located in principal-agent theory and focusses on the alignment of worker and organisational interests via share ownership encouraging agents (workers) to expend effort to achieve the principal's objectives. Since workers will benefit from high performance by the receipt of shares, dividends based on the shares and increases in the market value of the shares, they have an incentive to aim for high levels of performance. Although research in the economics tradition has typically been silent on the psychological processes involved, there is nevertheless an extensive body of literature on the impact of ESO on employee attitudes and behaviour. Commencing with the late Richard Long towards the end of the 1970s (Long, 1978a), this literature has either compared the attitudes and behaviour of share-owners/scheme-participants against non-participants within firms, across firms, and before and after scheme implementation.

This literature typically focusses on the effects of share ownership on the identification with and commitment of employees to their organisations. Long (1978a), for example, argued that share ownership increases organisational identification, which in turn has a positive impact upon firm performance. Rhodes and Steers (1981) comparative analysis of 
a worker-owned firm and a conventional firm in the plywood industry in the US reported higher commitment levels in the former. Furthermore, Pierce et al. (1991) and Pendleton et al. (1998) have drawn attention to the notion of psychological ownership, or feelings of ownership which, if present, can be expected to lead to higher commitment.

Not all of the evidence, however, has been so supportive. Gamble et al. (2002) found lower levels of commitment amongst employee shareholders, whilst other studies have found small and insignificant differences between share plan participants and non-participants (Baddon et al., 1989). Sengupta et al. (2007) found little evidence of a relationship between employee share schemes and organisational commitment. Some studies have suggested that schemes need to generate financial returns to employees (French and Rosenstein, 1984; Buchko, 1992) or provide employees with a role in decision making (Dube and Freeman, 2010; Kruse et al., 2012; Sengupta, 2008) to be effective. Others argued that these schemes should co-exist with high performance work practices (employee involvement, job security and training) to be effective (Kruse et al., 2010; Kurtulus and Kruse, 2017; Pendleton and Robinson, 2010).

A more general problem with the literature on the posited attitudinal effects of ESO is that it is extremely difficult to demonstrate linkages with organisational performance, even where there is strong evidence of positive relationships between ESO and employee attitudes (Pendleton et al., 1998). The range and levels of data necessary to systematically and convincingly demonstrate linkages between ESO and performance via the mediating role of employee attitudes has not been readily available. The British WERS have the range of workplaces to do this, and an employee survey linked to the workplace survey. However, since the employee survey does not observe share ownership any attempt to link ESO directly to commitment has to be treated with great caution.

For this reason, much of the research on the effects of ESO that uses the WERS surveys focusses directly on relationships between ESO and performance outcomes, and of mediating and moderating factors related to other organisational practices, rather than on the attitudinal states that ESO may bring about. In terms of the direct relationship between ESO and performance, the predominant approach draws on principal-agent theory to emphasise the potential alignment of employee and company interests. Against this, ESO clearly has some limitations. The potential for a free-rider effect may limit performance effects whilst transferring risk may impose some costs on employers (risk premiums). Most of the evidence from studies directly evaluating the links between ESO and performance finds positive effects of ESO (Bryson and Freeman, 2010; Kaarsemaker et al., 2009; Kruse et al., 2012; Kalmi et al., 2006; Poutsma and Braam, 2012; Robinson and Wilson, 2006; Sesil and Lin, 2011; Sesil and Kroumova, 2007; Blasi et al., 2016). A recent meta-analysis of 102 studies, representing over 56,000 firms, found that employee ownership has a small but positive and statistically significant relation to firm performance (O'Boyle et al., 2016). Focussing more narrowly on the WERS studies in the UK, conducted periodically since 1980, a series of studies have shown positive relationships between the use of ESO plans and workplace productivity and performance over the years (Gregg and Machin, 1988; Fernie and Metcalf, 1995; Pendleton, 1997; Heywood et al., 1997; McNabb and Whitfield, 1998; Addison and Belfield, 2000; Robinson and Zhang, 2005; Sengupta, 2008).

Based on these previous findings, coupled with the theoretical basis for predicting positive outcomes of ESO schemes, we propose:

H1. Workplaces with ESO schemes will exhibit higher levels of performance than those without.

Although the discussion above does not consider the means by which ESO may affect performance, it is nevertheless pertinent to enquire about the means through which such an 
PR

46,7

1284

outcome may be realised. Leaving aside the potential effects of ESO on employee attitudes, which cannot be directly tested using WERS, it is possible that ESO works through changes in employee behaviour (observed at the workplace rather than individual level). One approach suggests that share ownership schemes function primarily as a worker retention tool, and reduce labour turnover by making it financially lucrative for workers to remain in the firm and costly to leave it (Marsden, 1999; Morris et al., 2006; Pendleton and Robinson, 2011). Such an approach has been dubbed the "golden handcuffs hypothesis" (Sengupta et al., 2007). Share ownership plans typically have deferral characteristics which mean that the value of a particular tranche of shares is typically not realised for three to five years. In the UK Save As You Earn scheme, for example, employees can sign-up for options and saving schemes of three or five years duration, and do not receive any shares, should they choose to exercise the options, until then. Although participants in the Share Incentive Plan (SIP) become beneficial owners of their shares straight away, they are held in trust for at least three years. In many companies, any free or matching shares that are acquired through the SIP are forfeited if the employee leaves without good reason within three years. In the case of the Company Share Ownership Plan, options cannot be exercised until three years have elapsed.

The mechanics of share plans, then, serve to lock-in employees to the firm offering the share plan. Furthermore, in so far as grants of shares or options boost total wages above labour market norms, share plans can make it costly for employees to leave their employment. There is also a further reverse possibility in that, if employees select into optional share plans, share plan participation can reflect a reduced propensity to exit (Ewan and Macpherson, 2005).

There have been relatively few studies of the relationship between share plans and labour turnover, though the evidence is generally supportive of an inverse relationship (Fernie and Metcalf, 1995; Wilson et al., 1990; Robinson and Wilson, 2006). Other studies have found a reduced propensity to quit when data has been collected at the employee level (Blasi et al., 2008; Rhodes and Steer, 1981), though Gamble et al. (2002) found lower levels of behavioural commitment (intention to stay in the firm) amongst share plan participants. In the most recent study of ESO and turnover, using the 1998 WERS, Sengupta et al. (2007) found a significant negative relationship between share plan presence and labour turnover. On this basis, we advance our second hypothesis:

H2. Workplaces with share-ownership schemes will have lower turnover rates, other things being equal.

A critical issue is why lower levels of employee turnover might be associated with higher levels of organisational performance. Lower levels of employee turnover, encourage greater firm-specific and general human capital investment which contributes towards greater labour productivity and subsequently higher financial performance (Lincoln and Kalleberg, 2003; Richardson and Nejad, 1986). Sengupta et al. (2007) found considerable support for these propositions. ESO had a significant negative effect on labour turnover. When the relationship between ESO and performance was tested, a significant positive effect was observed: moreover, when the fitted values from the turnover regression were inserted into the performance equation, the ESO coefficient fell, whilst the residual inserted from the labour turnover regression was significant in the predicted direction. As a result, it can be anticipated that any positive association between share-ownership and performance would be lower in analyses where the impact of turnover had been allowed for, reflecting the mediating influence of the latter.

This is expressed in our third hypothesis:

H3. Part of any positive association between share-ownership and performance can be attributed to a negative impact of share-ownership on labour turnover. 
An alternative approach to investigation of the ways in which ESO affects workplace or company performance focusses on the moderating effects of other human resource practices (Kaarsemaker and Poutsma, 2006). This is based on the notion that practices will complement each other and that performance will benefit from these synergies. The ESO literature has focussed on two main sets of potential complements to ESO: training and employee involvement in decision making. Of the two, training is the less common and has been the subject of analysis only comparatively recently. Most of the limited literature in this area has been published since 2000 .

Recent WERS-based studies have shown that ESO is associated with higher levels of training within the firm (Pendleton and Robinson, 2011; Robinson and Zhang, 2005). A study based on the French REPONSE survey has shown that relatively high levels of training expenditure within the establishment have a positive impact on the introduction of ESO plans (Guery and Pendleton, 2016).

There are also grounds for anticipating that there will be a synergistic effect of training and ESO on performance. This is based on the "lock-in" capabilities of share plans and the capacity of share plan provision by management, along with involvement in the plans by employees, and reciprocal signals about commitment. Managers signal that they will not expropriate all the gains from training, whilst employees show that they will remain with the firm, thereby mitigating the risks for management of investing in training.

Based on this reasoning, we hypothesise that:

H4. Training will moderate the relationship between ESO and performance.

A long-standing perspective in the ESO literature argues that ESO will be more effective when combined with forms of employee participation in decision making. Analyses of such forms of participation generally identify a broad range of employee involvement practices, ranging from the provision of information by managers over and above a hypothetical minimum, through to a capacity or opportunity for employees to influence management decisions. The moderation effect of such practices is theoretically under-pinned by the weaknesses of agency theory in accounting for incentive effects of ESO. Since ESO is a group incentive, in theory its effectiveness may be undermined by the $1 / n$ issue. It is argued that combining ESO with various other forms of employee involvement will counter the $1 / n$ effect by showing over time ("repeated games") that effort and commitment are worthwhile (Kruse and Weitzman, 1990) and, if this fails to work, there is the potential for peer pressure via the institutions of employee involvement (Kruse et al., 2010). There is also a strain of literature, beginning with the "bundles" literature in the 1990s (e.g. MacDuffie, 1995), that argues that HRM practices will be more effective if they present a consistent approach to HRM (Ostroff and Bowen, 2000). On this basis, provision of greater information is consistent with the use of share ownership schemes, which require communication to employees on scheme details and share price performance.

WERS-based research over the years has provided partial support for these suppositions. Using the 1990 survey (WERS3), McNabb and Whitfield (1998) found that the effects of downward communication (briefing groups/team briefing, regular meetings between senior managers and the workforce, and regular newsletters) on financial performance was greater when operated in tandem with financial participation schemes in place (including ESO). Share ownership workplaces had positive effects on financial performance when combined with downward communication, but negative effects when these forms of downward communication were absent. By contrast, there were no effects on financial performance of operating upward forms of communication (quality circles and suggestion schemes), or representative participation (joint consultative committees). A replication of the McNabb and Whitfield study by Addison and Belfield using 1998 WERS generated rather different results. Share ownership was more likely to have a 
PR

46,7 positive effect on financial performance when upward communication was absent, indicating the opposite of complementarities, whilst share ownership had more or less similar effects on performance irrespective of the presence or absence of downward communication. Representative participation continued to have no effects. The implication of this is that share ownership plans impacted on performance in their own right.

Pendleton and Robinson (2010) found that share ownership had a positive relationship with above average levels of labour productivity in its own right especially where there were high levels of involvement in the share scheme. Downward communication could add to these effects whereas upward communication weakened the marginal effects of the share ownership scheme.

Based on these findings from various versions of the WERS survey, we hypothesise the following:

H5. The combination of ESO plans and downward communication schemes will have positive effects on workplace performance.

H6. The combination of ESO plans and upward communication schemes will have no significant effects on workplace performance.

\section{Methods \\ Data}

The analysis uses the workplace-level surveys ("the Management Questionnaire") from the 2004 and 2011 Workplace Employee Relations Surveys. The WERS data-sets provide comprehensive information on a nationally representative sample of firms in Britain. The Management Questionnaire was based on face-to-face interviews with senior managers in 2,295 establishments (response rate 64 per cent) in 2004 and 2,680 (response rate 46.3 per cent) in 2011. Data on the establishments include information on their structural characteristics, management employment practices, product markets, labour force composition and the nature of their collective employment relations.

The overall approach to test the hypotheses is to examine the effects of ESO on labour turnover, labour productivity, and financial performance in both years of observation, controlling for relevant characteristics such as sector and workplace size. Insertion of the fitted values derived from labour turnover regressions into performance regressions enables us to evaluate the moderating role of turnover. Then, we evaluate the potential moderating effects of upward involvement, downward communications, and training.

\section{Defining ESO}

The ESO measure records the presence of an ESO plan, that is, available to employees in the workplace. It takes the value 1 if any of the specified ESO plans in the survey are present in the workplace, 0 otherwise. It is a somewhat blunt measure of ESO but this form is adopted to permit comparability with the earlier studies of ESO, which also use a simple presence dummy. Two of the tax-approved schemes included in the measure are all-employee schemes, which are required to be open to all eligible employees (typically those with one year's tenure but sometimes less). The third is a discretionary scheme, which companies can restrict to selected employees, but most workplaces with these schemes operated them as all-employee schemes (Pendleton, 2007).

The percentage of private sector workplaces with share ownership plans in 2004 was 19 per cent, more or less the same as in 1998 (Kersley et al., 2006). However, the incidence had fallen to 10 per cent by 2011 (Van Wanrooy et al., 2013). 
Turnover variable

The turnover variable is based on a question asked of the manager most responsible for personnel about the number of permanent employees who stopped working at the workplace in the last five years because they resigned voluntarily. The variable used in the analysis is the turnover rate - the number of permanent employees leaving the workplace divided by the number of permanent employees at the time of the survey. The variable is expressed in logarithmic form (natural log) to reflect bunching at one end of the distribution.
ESO and organisational performance

\section{Performance variables}

In both WERS2004 and WERS2011, the measures of performance are qualitative, and are derived from manager assessments of what is happening in their own establishment relative to what they believe is happening in other establishments in the same industry. Two dimensions of performance are considered, financial performance and labour productivity. The variables used in the performance analyses are binary, taking the value " 1 " if the workplace has above average performance and " 0 " otherwise. Though both surveys allow the option of using objective measures of performance the preference was to rely on the subjective performance measures for several reasons. First, several studies have validated the reliability of the subjective performance measures (Machin and Stewart, 1996). Second, the objective performance measures were available for only around 40 per cent of workplaces in comparison to the subjective performance measures that were available for 2,295 workplaces, thereby restricting the sample size considerable. Besides, the subjective measures are a useful alternative to objective performance measures which have limitations of their own (Machin and Stewart, 1996).

The moderating variables are based on these used in McNabb and Whitfield (1998), which in turn were based on well-established conceptualisations in the literature. Upward involvement is a composite dummy variable recording the presence of quality circles, problem-solving groups, or suggestion schemes. It does not include representative forms of involvement in decisions or formal means for influencing management decisions such as consultative committees (previous analyses of ESO have found these have no effects on workplace performance). Downward communication records the presence of team briefings, newsletters, and meetings held by senior managers with all employees. The training variable records how much off-the-job training is offered to members of the largest occupational group in the workplace, with the value set at 1 where employees receive five days or more each year, 0 otherwise. We experimented with an alternative measure of training, based on the proportion of employees who receive training each year, but the results were not materially different, and hence are not reported here.

\section{Statistical methods}

All of the analysis is based on a sub-set of the WERS workplaces - those that are to be found in the private trading sector $(n=635$ in 2004, 653 in 2011). This provides continuity with earlier analyses against which the results are compared. All regressions utilise the workplace weights supplied with the WERS data, and include a vector of control variables based on previous research in the area. Since the dependent variables are binomial, the performance regressions use probit analysis, whilst the regression of quits on ESO uses ordinary least squares (OLS) analysis. The moderation analysis is conducted using interaction terms which, since they are based on dummies, take a categorical form. As the dependent variables are binomial, this obviates the need to plot the values of the interaction terms at each level of the dependent variable, and hence the main results are relatively straightforward to present. 
PR

46,7

1288

Table I.

Probit analysis of employee share ownership and labour productivity

\section{Results}

Share ownership and performance

The baseline results for the performance relationships are presented in Tables I and II. The first of these tables presents results for ESO and labour productivity, whilst the second displays the results for ESO and financial performance. The headline result is that, controlling for sector, size and various other forms of employee participation, ESO has a significant positive relationship with both labour productivity, consistent with other studies in this area (Pendleton and Robinson, 2010), and financial performance in 2004. However, in 2011, ESO has significant relationships with neither labour productivity nor financial performance, interrupting a tradition of observed positive associations of ESO dating back to the $1990 \mathrm{WIRS}$. The coefficients for upward involvement downward communication, and for training, are mostly insignificant in these models.

On the basis of these results, we judge $H 1$ to be partially supported.

H2 proposes that workplaces with ESO will have lower levels of turnover than those without, after controlling for other workplace characteristics that may be associated with labour turnover. The results for the regressions evaluating the relationship between ESO and turnover are found in Table III.

\begin{tabular}{|c|c|c|}
\hline Independent and control variables & WERS2004 & WERS2011 \\
\hline Presence of share ownership & $0.451^{* *}$ & -0.004 \\
\hline \multicolumn{3}{|l|}{ Establishment characteristics } \\
\hline Recognised union at establishment & -0.089 & 0.033 \\
\hline Level of technology: Percentage of unskilled workers & -0.182 & -0.055 \\
\hline Establishment age: $>20$ years & -0.035 & 0.201 \\
\hline Number of employees (multiplied by 1000) & 0.008 & -0.003 \\
\hline Establishment status: Independent establishment & $0.563^{* * * *}$ & 0.156 \\
\hline \multicolumn{3}{|l|}{ Sectors } \\
\hline Manufacturing & -0.543 & 0.027 \\
\hline Public administration & -0.064 & -0.635 \\
\hline Education & $-1.038^{*}$ & 0.440 \\
\hline Health & -0.326 & 0.136 \\
\hline Electricity, gas and water & -0.115 & $-1.33^{* * *}$ \\
\hline Construction & -0.818 & 0.742 \\
\hline Wholesale and retail & -0.328 & 0.420 \\
\hline Hotels and restaurants & -0.205 & 0.366 \\
\hline Transport and communications & -0.218 & 0.588 \\
\hline Financial services & $-0.970^{*}$ & 0.490 \\
\hline Other business services & -0.445 & 0.131 \\
\hline \multicolumn{3}{|l|}{ Market characteristics } \\
\hline Market growth & 0.163 & -0.026 \\
\hline International market & $0.353^{*}$ & $0.418^{*}$ \\
\hline Product market competition (high competition for main product or services) & -0.209 & -0.091 \\
\hline \multicolumn{3}{|l|}{ Human resource practices } \\
\hline Upward communication & -0.118 & 0.037 \\
\hline Downward Communication & -0.173 & $0.878^{*}$ \\
\hline Training & 0.202 & 0.143 \\
\hline Constant & 0.289 & $-1.06^{*}$ \\
\hline Number of observations & 635 & 653 \\
\hline Pseudo $\mathrm{R}^{2}$ & 0.07 & 0.04 \\
\hline
\end{tabular}




\begin{tabular}{|c|c|c|c|}
\hline Independent and control variables & WERS2004 & WERS2011 & Esu and \\
\hline $\begin{array}{l}\text { Presence of Share-Ownership } \\
\text { Establishment characteristics }\end{array}$ & $0.604 * * *$ & 0.283 & performance \\
\hline Recognised union at establishment & $-0.429 *$ & 0.076 & \\
\hline Level of technology: Percentage of unskilled workers & 0.017 & -0.243 & \\
\hline Establishment age $>20$ years & 0.005 & 0.282 & \\
\hline Number of employees (multiplied by 1000) & 0.002 & 0.009 & 128 \\
\hline Establishment status: independent establishment & 0.003 & -0.233 & \\
\hline \multicolumn{4}{|l|}{ Sectors } \\
\hline Manufacturing & -0.118 & 0.406 & \\
\hline Public administration & -0.184 & 0.617 & \\
\hline Education & -0.539 & 0.302 & \\
\hline Health & 0.257 & 0.484 & \\
\hline Electricity, gas and water & 0.723 & -0.742 & \\
\hline Construction & 0.092 & 0.364 & \\
\hline Wholesale and retail & -0.027 & $0.796^{* *}$ & \\
\hline Hotels and restaurants & 0.657 & 0.696 & \\
\hline Transport and communications & 0.554 & $1.03 * * *$ & \\
\hline Financial services & 0.206 & $1.39 * * *$ & \\
\hline Other business services & -0.394 & $0.603^{* *}$ & \\
\hline \multicolumn{4}{|l|}{ Market characteristics } \\
\hline Market growth & $0.298^{*}$ & 0.097 & \\
\hline International market & -0.063 & 0.065 & \\
\hline Product market competition (high competition for main product or services) & $-0.452^{* * * *}$ & -0.189 & \\
\hline \multicolumn{4}{|l|}{ Human resource practices } \\
\hline Upward Communication & 0.044 & -0.231 & \\
\hline Downward Communication & -0.212 & 0.253 & \\
\hline Training & 0.238 & -0.174 & \\
\hline Constant & 0.305 & -0.719 & Probit analysis of \\
\hline Number of observations & 635 & 653 & employee share \\
\hline Pseudo $\mathrm{R}^{2}$ & 0.09 & 0.06 & \\
\hline \multicolumn{3}{|l|}{ Notes: $* * *, * * *$ Significant at 10,5 and 1 per cent levels, respectively } & financial performance \\
\hline
\end{tabular}

The results presented in Table III suggest that there is a negative, but insignificant, relationship between ESO and employee turnover, other relevant factors being controlled for. The possibility that the lower levels of employee turnover in share ownership establishments are attributable to the high wages paid in these establishments (Blair and Kruse, 1999) is tested by controlling for the proportion of full-time employees earning below $£ 9000$ pa and above $£ 29000$ pa. Neither variable is significant at the ten per cent level.

On the basis of these results, it is safe to conclude that $H 2$ is not supported. The suggestion therefore that the often-found positive relationship between share ownership and performance could result from its influence on the quit-rate, by helping the firm to economise on hiring/firing costs and protecting valuable investments in firm specific human capital, is not supported by these results. There seems to be little evidence of ESO functioning as "golden handcuffs" (Sengupta et al., 2007).

$H 3$, that the performance effect of ESO operates in part via lower labour turnover, becomes somewhat redundant given the results above. However, for completeness we report the results for regressions of performance on ESO with the residual values from the labour turnover regressions inserted. In this way, we are controlling for the indirect effect of share ownership on performance via its effect on employee turnover. The coefficients on share ownership then measure the direct or net effect on performance. 
PR

46,7

\begin{tabular}{|c|c|c|}
\hline Independent and control variables & $\begin{array}{l}\text { WERS2004 } \\
\text { Coefficient }\end{array}$ & $\begin{array}{c}\text { WERS2011 } \\
\text { Coefficient }\end{array}$ \\
\hline Presence of share-ownership & -0.003 & -0.056 \\
\hline $\begin{array}{l}\text { Sectors } \\
\text { Manufacturing } \\
\text { Public administration } \\
\text { Education } \\
\text { Health and social work } \\
\text { Electricity, gas and water } \\
\text { Construction } \\
\text { Wholesale and retail } \\
\text { Hotels and restaurants } \\
\text { Transport and communications } \\
\text { Financial services } \\
\text { Other business services }\end{array}$ & $\begin{array}{c}-0.203 \\
-0.366 \\
-0.238 \\
0.031 \\
-1.062^{* * *} \\
0.574 * * \\
0.242 \\
0.261 \\
-0.124 \\
0.011 \\
0.132\end{array}$ & $\begin{array}{l}-0.139 \\
-2.245^{* * *} \\
-.0-0.555^{* * *} \\
-0.381^{* * *} \\
0.315 \\
-0.351^{*} \\
-0.175 \\
-0.917^{* * *} \\
0.098 \\
-0.552^{*} \\
-0.129\end{array}$ \\
\hline $\begin{array}{l}\text { Establishment characteristics } \\
\text { Number of employees (multiplied by } 1000 \text { ) } \\
\text { Establishment status: independent establishment } \\
\text { Private sector } \\
\text { Recognised union at establishment } \\
\text { Procedures dealing with collective disputes } \\
\text { Proportion of part-time workers } \\
\text { Proportion of female workers } \\
\text { Proportion of ethnic workers } \\
\text { Proportion of workers aged under } 21 \\
\% \text { full-time employees earning }<£ 9000 \text { p.a } \\
\% \text { full-time employees earning }>£ 29000 \text { p.a }\end{array}$ & $\begin{array}{l}0.008^{* * *} \\
-0.091 \\
-0.333 \\
-0.436^{* * *} \\
0.016 \\
0.350^{*} \\
-0.341^{*} \\
0.422^{*} \\
0.454^{* *} \\
-0.240 \\
-0.402^{* *}\end{array}$ & $\begin{array}{c}0.001^{*} \\
-0.097 \\
-0.374 \\
-0.449 \\
-0.075 \\
0.307^{*} \\
0.374^{*} \\
0.102 \\
-0.116 \\
0.051 \\
.-0.193\end{array}$ \\
\hline $\begin{array}{l}\text { Human resource practices } \\
\text { Upward Communication } \\
\text { Downward Communication } \\
\text { Training } \\
\text { Constant } \\
\text { Number of observations } \\
R^{2}\end{array}$ & $\begin{array}{l}0.080 \\
0.188 \\
-0.061 \\
-1.566^{* * *} \\
635 \\
0.24\end{array}$ & $\begin{array}{c}-0.132 \\
0.077 \\
0.178 \\
-1.62^{* * * *} \\
653 \\
0.21\end{array}$ \\
\hline
\end{tabular}

Table III.

Least squares analysis of employee turnover

Unsurprisingly, the fitted values have insignificant effects on labour productivity and financial performance in both years and the ESO coefficients changes little from those reported in Tables I and II. $H 3$ is therefore not supported.

H4-H6 make a series of predictions about the moderating effects of other HRM practices. The extent of moderation is shown using interaction terms whereby the variables of interest are multiplied by the ESO variable. The results are presented for both years of observation in Tables IV and V. The first of these reports results for labour productivity, whilst the second presents those for financial performance. The first column for each year presents the coefficients for the constituent variables of the interaction term, whilst the second column presents the coefficients for the interaction term and the constituent items once the interaction term has been inserted.

Looking at labour productivity first in Table III, the moderation of ESO by downward communication is strongly significant, with the ESO constituent term becoming significantly negative in 2004. This suggests that the positive effects of ESO are concentrated in cases where there is also downward communication. ESO on its own, without downward communication, has negative effects on productivity. A positive 


\begin{tabular}{|c|c|c|c|c|c|}
\hline & WERS 2004 & WERS 2004 & WERS 2011 & WERS 2011 & anis \\
\hline Presence of share ownership (ESO) & $0.451 * *$ & $-4.378^{* * *}$ & -0.004 & $-4.784^{* * * *}$ & performance \\
\hline Training & 0.203 & 0.035 & 0.143 & 0.255 & \\
\hline Upward invo & -0.118 & 0.020 & 0.037 & 0.005 & \\
\hline Downward communication & -0.173 & -0.087 & $0.878^{*}$ & 0.682 & \\
\hline $\mathrm{ESO} \times$ training & & 0.569 & & -0.496 & \\
\hline ESO $\times$ upward involvement & & -0.305 & & 0.175 & 1 \\
\hline $\begin{array}{l}\text { ESO } \times \text { downward communication } \\
\text { Quits }\end{array}$ & & $\begin{array}{l}4.859 * * * \\
-0.317\end{array}$ & & $\begin{array}{l}4.935^{* * * *} \\
0.097\end{array}$ & Table IV. \\
\hline $\begin{array}{l}\text { Quits } \\
N\end{array}$ & 635 & $\begin{array}{r}-0.011 \\
635\end{array}$ & 653 & $\begin{array}{r}0.091 \\
653\end{array}$ & \\
\hline Pseudo $R^{2}$ & 0.07 & 0.08 & 0.04 & 0.05 & $\begin{array}{l}\text { employe } \\
\text { rship and }\end{array}$ \\
\hline \multicolumn{5}{|c|}{$\begin{array}{l}\text { Notes: The same control variables have been included in the regression model as for regressions reported in } \\
\text { Tables I and II, but are not shown here. } * * * * * * \text { Significant at } 10,5 \text { and } 1 \text { per cent levels, respectively }\end{array}$} & $\begin{array}{r}\text { productivity } \\
\text { moderation analysi }\end{array}$ \\
\hline
\end{tabular}

\begin{tabular}{lcccc}
\hline & WERS 2004 & WERS 2004 & WERS 2011 & WERS 2011 \\
\hline Presence of share ownership (ESO) & $0.604^{* * * *}$ & $-3.688^{* * * *}$ & 0.284 & 0.979 \\
Training & 0.238 & -0.004 & -0.174 & -0.060 \\
Upward involvement & 0.044 & 0.068 & -0.231 & -0.327 \\
Downward communication & -0.212 & -0.152 & 0.253 & 0.427 \\
ESO $\times$ training & & $1.251^{* * *}$ & & 0.118 \\
ESO $\times$ upward involvement & & -0.072 & & -0.123 \\
ESO $\times$ downward communication & & $3.948^{* * *}$ & & -0.799 \\
Quits & 635 & -0.021 & 635 & -0.780 \\
$N$ & 0.09 & 0.11 & 0.06 & 653 \\
Pseudo $R^{2}$ & & & 0.06 & 0.07
\end{tabular}

Notes: The same control variables have been included in the regression model as for regressions reported in Tables I and II, but are not shown here. *******Significant at 10, 5 and 1 per cent levels, respectively

Table V.

Probit analysis of employee share ownership and financial performance: moderation analysis

interaction effect is also observed in 2011, alongside a negative effect of ESO when communication is absent.

Neither upward involvement nor training has significant moderating effects on the effects of ESO on labour productivity, in either 2004 or 2011. The upward involvement results are consistent with those observed in earlier analyses including those using 2004. The results for training are more novel but, in conjunction with the labour turnover results, they provide little support for those theoretical perspectives emphasising the role of ESO in developing human capital.

In Table $\mathrm{V}$ the results for the moderating effects of upward involvement, downward communication, and training in relation to financial performance are less clear-cut than those relating to labour productivity. The interaction terms for ESO and downward communication, and for training and ESO, are positive and significant in 2004 but there are no positive moderation effects in 2011.

On the basis of these results we can claim that $H 4$ (training) is partially supported, $H 5$ (downward communication) is supported except for financial performance in 2011, and $H 6$ (upward involvement) is not supported in any instance.

Summarising these results, the following claims can be made. ESO has positive performance effects on both labour productivity and financial performance in 2004 but not 2011, suggesting that the effects of ESO have weakened over time or because of some event or changes that have occurred between 2004 and 2011. There is no evidence of ESO reducing labour turnover, and hence it is unlikely that the positive effects of ESO observed 
PR

46,7

1292

in 2004 are secured via this route. Thus the "golden handcuffs" perspective is not supported. Finally, there is evidence consistent with the earlier WERS studies that ESO has a synergistic relationship with downward communication but not upward involvement. As for training, there is not a great deal of evidence for the view, recently expressed in the literature, that ESO may achieve its effects via a synergistic relationship with employerprovided training.

\section{Conclusions, implication and limitations}

The findings in this paper contribute to the academic debate on ESO and performance in a number of ways. In many respects, our findings add weight to the scepticism, voiced by Tom Redman, about the power of share-ownership to leverage high organisational performance, either in its own right or in combination with other HR practices. Primarily, the paper challenges conventional wisdom that ESO schemes impact upon performance by acting as an effective retention tool by making it more lucrative for employees to remain with the firm. These findings call into question the findings from the previous research using the WERS 98 data set (Sengupta et al., 2007). Instead, attention is diverted to the contingency argument which emphasises the importance of the presence of supportive workplace practices that need to be in place (such as employee involvement, job security, training and low supervision). However, only some practices seem to have this effect. It has been argued elsewhere that without such supportive policies ESO schemes may have lower satisfaction and higher employee turnover (Kruse, 2016). ESO schemes without the presence of supportive workplace policies may be viewed as an attempt to shift financial risk onto the workers rather than to empower them (Kruse, 2016; Kruse et al., 2010; Kruse and Kurtulus, 2017). Our results are consistent with this argument in that the use of ESO schemes without downward communication is negatively related to productivity in both 2004 and 2011, and with financial performance in 2004.

These effects are likely to be more pronounced during recession. We find that ESO has insignificant associations with labour productivity and financial performance in 2011. This finding is consistent with the view that during recession the relative productivity advantage of ESO firms declines because employee ownership firms lay off fewer workers during recession. The lack of higher productivity may be due to retaining workers who receive new training or otherwise invest in activities that bolster long-term but not short-term productivity (Kruse, 2016, p. 5). This finding also lends further support to the evidence which shows that economic conditions could impact labour productivity in ESO firms, thus drawing attention to the role of contextual factors in shaping ESO effectiveness.

The findings also have implications for managerial practitioners and companies considering the implementation of a share scheme. The results would enable them to have a more realistic view of the expected benefits and the costs associated with the different types of share ownership schemes, thereby influencing their decision on whether to invest in a share scheme. The findings have implications for policy-makers who determine the incentives that should be given to encourage companies to adopt share ownership schemes. When the mere existence of share schemes is no guarantee for boosting organisational performance, bringing about a more equitable distribution of wealth, policy-makers may wish to reconsider whether or not to encourage their adoption or to advocate tax breaks.

Some caution must; however, be applied to the conclusions reached in this study. This particularly applies to the cross-sectional nature of the data-set and the potential for reverse causality especially regarding financial performance. The problem of causality can be addressed by using panel data, or by designing longitudinal studies with different samples. Qualitative data could add value by providing insights into the causal processes. A case is thereby made for encouraging a tradition of collaborative research employing both quantitative and qualitative analysis techniques. We hope that Tom would have approved. 


\section{References}

Addison, J. and Belfield, C. (2000), "Updating the determinants of firm performance: estimation using the 1998 UK workplace employee relations survey”, British Journal of Industrial Relations, Vol. 39 No. 3, pp. 341-366.

Appelbaum, E. and Batt, R. (1994), The New American Workplace: Transforming Work Systems in the United States, ILR Press, Ithaca, NY.

Baddon, L., Hunter, L., Hyman, J., Leopold, J. and Ramsay, H. (1989), People’s capitalism?: A critical Analysis of Profit Sharing and Employee Share Ownership, Routledge, London.

Blair, M. and Kruse, D. (1999), "Giving employees an ownership stake”, Brookings Review, Fall.

Blasi, J., Freeman, R. and Kruse, D. (2016), "Do broad-based employee ownership, profit sharing and stock options help the best firms do even better?", British Journal of Industrial Relations, Vol. 54 No. 1 , pp. $55-82$.

Blasi, J., Kruse, D., Sesil, J. and Kroumova, M. (2003), “An assessment of employee ownership in the United States with implications for the EU", International Journal of Human Resource Management, Vol. 14 No. 6, pp. 893-919.

Bryson, A. and Freeman, R. (2010), "How does shared capitalism affect economic performance in the United Kingdom?", Shared Capitalism at Work: Employee Ownership, Profit and Gain Sharing, and Broad-Based Stock Options, University of Chicago Press, Chicago, pp. 201-224.

Buchko, A. (1992), "Effects of employee ownership on employee attitudes", Work \& Occupations, Vol. 19 No. 1, pp. 59-78.

Dube, A. and Freeman, R. (2010), "Complementarity of shared compensation and decision-making systems: evidence from the American labor market", in Kruse, D. et al. (Eds), Shared Capitalism at Work: Employee Ownership, Profit and Gain Sharing, and Broad-based Stock Options, University of Chicago Press, Chicago, pp. 167-199.

Ewan, W. and Macpherson, D. (2005), "The effects of employer matching in 401(k) plans", Industrial Relations, Vol. 44 No. 3, pp. 525-549.

Fernie, S. and Metcalf, D. (1995), "Participation, contingent pay, representation and workplace performance: evidence from Great Britain”, British Journal of Industrial Relations, Vol. 33 No. 3, pp. 379-415.

French, J. and Rosenstein, J. (1984), "Employee ownership work attitudes, and power relationships", Academy of Management Journal, Vol. 27 No. 4, pp. 861-869.

Gamble, J., Culpepper, R. and Blubaugh, M. (2002), "ESOPs and employee attitudes: The importance of empowerment and financial value", Personnel Review, Vol. 31 No. 1, pp. 9-26.

Gregg, P. and Machin, S. (1988), "Unions and the incidence of performance linked pay schemes", International Journal of Industrial Organization, Vol. 6 No. 1, pp. 91-107.

Guery, L. and Pendleton, A. (2016), "Do investments in human capital lead to employee share ownership? Evidence from French establishments", Economic and Industrial Democracy, Vol. 37 No. 3, pp. 567-591.

Heywood, J.S., Siebert, W.S. and Xiandong, W. (1997), "Payment by results systems: British evidence", British Journal of Industrial Relations, Vol. 35 No. 1, pp. 1-22.

Kaarsemaker, E. and Poutsma, E. (2006), "The fit of employee ownership with other human resource management practices: theoretical and empirical suggestions regarding the existence of an ownership high-performance work system, or theory O", Economic and Industrial Democracy, Vol. 27 No. 2, pp. 669-685.

Kaarsemaker, E., Pendleton, A. and Poutsma, E. (2009), "Employee share ownership plans", in Wilkinson, A., Gollan, P., Marchington, M. and Lewin, D. (Eds), The Oxford Handbook of Participation in Organizations, Oxford University Press, Oxford, pp. 315-337.

Kersley, B., Alpin, C., Forth, J., Bryson, A., Bewley, H., Dix, G. and Oxenbridge, S. (2006), Inside the Workplace: Findings from the 2004 Workplace Employment Relations Survey, Routledge, London. organisational performance

1293 
PR

46,7

Kruse, D. (2016), "Does employee ownership improve performance?”, IZA World of Labor, p. 311, doi: 10.15185/izawol.311. wol.iza.org.

Kruse, D., Blasi, J. and Freeman, R. (2012), Does Linking Worker Pay to Firm Performance Help the Best Firms Do Even Better? (No. w17745), National Bureau of Economic Research, New York, NY.

Kruse, D., Freeman, R. and Blasi, J. (2010), Shared Capitalism at Work: Employee Ownership, Profit and Gain Sharing, and Broad-based Stock Options, University of Chicago Press, Chicago, IL.

Kurtulus, F.A. and Kruse, D.L. (2017), How Did Employee Ownership Firms Weather the Last Two Recessions?: Employee Ownership, Employment Stability, and Firm Survival in the United States: 1999-2011, W.E. Upjohn Institute for Employment Research, Kalamazoo, MI.

Lincoln, J. and Kalleberg, A. (1990), A Study of Work Organization and Work Attitudes in the United States and Japan, Cambridge.

Long, R.J. (1978a), "The relative effects of share ownership vs. control on job attitudes in an employee-owned company", Human Relations, Vol. 31 No. 9, pp. 753-763.

MacDuffie, J.-P. (1995), "Human resource bundles and manufacturing performance: organizational logic and flexible production systems in the world auto industry", Industrial and Labor Relations Review, Vol. 48 No. 2, pp. 197-221.

McNabb, R. and Whitfield, K. (1998), "The impact of financial participation and employee involvement on financial performance", Scottish Journal of Political Economy, Vol. 45 No. 2, pp. 171-187.

Machin, S. and Stewart, M. (1996), "Trade unions and financial performance", Oxford Economic Papers, Vol. 48 No. 1, pp. 213-241.

Marsden, D. (1999), A Theory of Employment Systems, Oxford University Press, Oxford.

Morris, D., Bakan, I. and Wood, G. (2006), "Employee financial participation: evidence from a major UK retailer", Employee Relations, Vol. 28 No. 4, pp. 326-341.

O'Boyle, E., Patel, P. and Gonzalez-Mule, E. (2016), "Employee ownership and firm performance: a meta-analysis", Human Resource Management Journal, Vol. 26 No. 4, pp. 425-448.

Ostroff, C. and Bowen, D.E. (2000), "Moving HR to a higher level. HR practices and organizational effectiveness", in Klein, K.J. and Kozlowski, S.W.J. (Eds), Multilevel Theory, Research, and Methods in Organizational Psychology, Jossey-Bass, San Francisco, CA, pp. 211-266.

Paauwe, J. (2004), HRM and Performance: Achieving Long Term Viability, Oxford University Press, Oxford.

Pendleton, A. (1997), "Characteristics of workplaces with financial participation: evidence from the workplace industrial relations survey", Industrial Relations Journal, Vol. 28 No. 2, pp. 103-119.

Pendleton, A. (2006), "Incentives, monitoring, and employee stock ownership plans: new evidence and interpretations", Industrial Relations: A Journal of Economy and Society, Vol. 45 No. 4, pp. 753-777.

Pendleton, A. (2007), "The study of employee share ownership using WERS: an evaluation and analysis of the 2004 survey", in Whitfield, K. and Huxley, K. (Ed.), Innovations in the 2004 Workplace Employment Relations Survey, Cardiff University, Cardiff, pp. 56-71.

Pendleton, A. and Robinson, A. (2010), "Employee stock ownership, involvement and productivity: an interaction-based approach", Industrial and Labor Relations Review, Vol. 64 No. 1, pp. 746-772.

Pendleton, A. and Robinson, A. (2011), "Employee share ownership and human capital development: complementarity in theory and practice", Economic and Industrial Democracy, Vol. 32 No. 3, pp. 439-457.

Pendleton, A., Wilson, N. and Wright, M. (1998), "The perception and effects of share ownership: Empirical evidence from employee buy-outs", British Journal of Industrial Relations, Vol. 36 No. 1, pp. 99-123. 
Pierce, J.L., Rubenfeld, S.A. and Morgan, S. (1991), "Employee ownership: a conceptual model of process and effects", Academy of Management Review, Vol. 16 No. 1, pp. 121-144.

Poutsma, E. and Braam, G. (2012), "Financial participation plans and firm fFinancial performance: evidence from a Dutch longitudinal panel", Advances in the Economic Analysis of Participatory \& Labor-Managed Firms, Vol. 13, pp. 139-183.

Richardson, R. and Nejad, A. (1986), "Employee share ownership schemes in the UK - an evaluation”, British Journal of Industrial Relations, Vol. 24 No. 2, pp. 233-244.

Rhodes, S. and Steers, R. (1981), “A systematic approach to diagnosing employee absenteeism”, Employee Relations, Vol. 3 No. 2, pp. 17-22.

Robinson, A. and Wilson, N. (2006), "Employee financial participation and productivity: an empirical reappraisal", British Journal of Industrial Relations, Vol. 44 No. 1, pp. 31-50.

Robinson, A. and Zhang, H. (2005), "Employee share ownership: safeguarding investments in human capital”, British Journal of Industrial Relations, Vol. 43 No. 3, pp. 469-488.

Sengupta, S. (2008), "The impact of employee share-ownership schemes on performance in unionised and non-unionised workplaces", Industrial Relations Journal, Vol. 39 No. 3, pp. 170-190.

Sengupta, S., Whitfield, K. and McNabb, R. (2007), "Employee share ownership and performance: golden path or golden handcuffs?", International Journal of Human Resource Management, Vol. 18 No. 8, pp. 1507-1538.

Sesil, J. and Kroumova, M. (2007), "Broad-based stock options: before and after the market downturn", The International Journal of Human Resource Management, Vol. 18 No. 8, pp. 1471-1485.

Van Wanrooy, B., Bewley, H., Bryson, A., Forth, J., Freeth, S., Stokes, L. and Wood, S. (2013), Employment Relations in the Shadow of the Recession. Findings from the 2011 Workplace Employment Relations Survey, Palgrave Macmillan, Basingstoke.

Weitzman, M.L. and Kruse, D.L. (1990), "Profit sharing and productivity”, in Blinder, A.S. (Ed.), Paying for Productivity: A Look at the Evidence, Center for Economic Progress and Employment Series, Brookings Institution, Washington, DC, pp. 95-140.

Whitfield, K. and Poole, M. (1997), "Organizing employment for high performance: theories, evidence and policy”, Organization Studies, Vol. 18 No. 5, pp. 745-764.

Wilson, N., Cable, J.R. and Peel, M.J. (1990), "Quit rates and the impact of participation, profit-sharing and unionization: empirical evidence form UK engineering firms", British Journal of Industrial Relations, Vol. 28 No. 2, pp. 197-213.

\section{Further reading}

Addison, J. and Belfield, C. (2003), "The impact of financial participation and employee involvement on financial performance: a re-estimation using the 1998 WERS”, Scottish Journal of Political Economy, Vol. 47 No. 5, pp. 571-583.

Blanchflower Conte, M.A. and Svejnar, J. (1988), "Productivity effects of worker participation in management, profit-sharing, worker ownership of assets and unionization in US Firms", International Journal of Industrial Organization, Vol. 6 No. 1, pp. 139-151.

Dunn, S., Richardson, R. and Dewe, P. (1991), "The impact of employee share ownership on worker attitudes: a longitudinal case study”, Human Resource Management Journal, Vol. 1 No. 3, pp. 1-17.

Gray, M. (2007), Increase in the Extent of Performance Related Pay, IRRU, Warwick University, available at: www.eurofound.europa.eu/eiro/2006/12/articles/uk0612059i.htm

Guest, D. (1995), "Human resource management, trade unions and industrial relations", in Storey, J. (Ed.), Human Resource Management: A Critical text, International Thomson Business Press, London, pp. 100-141.

Kalmi, P., Pendleton, A. and Poutsma, E. (2006), "Financial participation and performance in Europe", Human Resource Management Journal, Vol. 15 No. 4, pp. 54-67. 
PR

46,7

1296

Klein, S.M. (1973), "Pay factors as predictors to satisfaction: a comparison of reinforcement, equity, and expectancy", Academy of Management Journal, Vol. 16 No. 4, pp. 598-610.

Kim, K.Y. and Patel, P.C. (2017), "Employee ownership and firm performance: a variance decomposition analysis of European firms", Journal of Business Research, Vol. 70 No. 1, pp. 248-254.

Kruse, D. (1984), Employee Ownership and Employee Attitudes: Two Case Studies, Norwood Editions, Norwood PA.

Long, R.J. (1978b), "The effects of employee ownership on organisational identification, employee job attitudes, and organisational performance: a tentative framework and empirical findings", Human Relations, Vol. 31 No. 1, pp. 29-48.

Sesil, J. and Lin, Y. (2005), "Executive and broad-based stock options: evidence from US panel data", Curriculum Library for Employee Ownership, Rutgers University, NJ.

\section{Corresponding author}

Keith Whitfield can be contacted at: whitfield@cf.ac.uk

For instructions on how to order reprints of this article, please visit our website: 